\title{
THE BREAKING-UP OF THE ICE ON THE ST. MARY'S RIVER, NOVA SCOTIA, AND ITS GEOLOGICAL LESSONS,
}

\author{
BY G. F. MONCK'TON. \\ [Read Ist December, 1893.]
}

\begin{abstract}
A STATEMENT of facts relating to the breaking-up of the ice $A$ on a large river in Nova Scotia may be of interest to those who, in the mild climate of England, have no opportunity of seeing such an event.
\end{abstract}

In Nova Scotia the extremes of heat and cold are greater than in England, and the rivers are often covered with ice more than a foot thick. The river to which my remarks refer is the St. Mary's River, the main stream of which has a length of about sixty miles. IVith its tributaries it drains about 600 square miles. At the head of the tide at Sherbrooke it has a normal discharge in spring of about 6,000,000 cubic feet per hour, and in summer J,500,000 cubic feet per hour. It has a fall of about eight feet to the mile just above that point.

This year it was colder than usual. The thermometer, which rarely falls lower than $5^{\circ}$ below zero, fell on several occasions to ten, and on two occasions to eighteen degrees lower. The ice, therefore, was thicker than usual and only broke up twice. Usually it breaks up and goes out to sea three times. Some of it, however, just previous to the second break, having broken, floated down and caught under the solid ice below the Sherbrooke Bridge. Here it may be mentioned that once in every few years the ice above, having broken before the solid ice below Sherbrooke, has caught against the solid sheet and dammed up the waters, flooding some one hundred acres, and depositing on them large quantities of boulders and gravel. The ice-cakes have on these occasions done great damage, forcing wooden barns and other buildings off their foundations and pushing them through the shallow water into the river current. In the year I $88 \mathrm{I}$ the river was raised in this manner fifteen feet above its usual level.

Ice, in these rivers, is formed at first at the bottom, round stones where the current flows slowly. As the piece grows it lifts the stone off the bottom and floats it away. When this anchor ice, as it is called, is coming down in quantity it accumulates in the eddies, and, freezing into large cakes, soon gives rise to a solid sheet across the river at that point. The ice, therefore, at such points is very thick, and may hold the rest back for some time if it breaks above this point.

February, r 895.] 
On February I 2 th, during a thaw, all the ice on the river for three miles above the bridge broke and came down. It broke off in portions from too to 500 yards long, and as there was an interval between the breaking of each of these lengths, each one had time to jam and back up the water before the next portion floated down. Part of each of these lengths would thus be floated over the one in front of it. in many places two, three, and even four cakes were lying on one another, each a foot or more in thickness. There was not much water in the river on this occasion, but the jam of ice raised it at the bend six feet in two hours. In one place ice cakes were floated on to the road eight feet above the ordinary spring water level. The shock of these ice-fields, 200 feet wide and 300 yards long, was very great, especially. as most of the ice came down in unbroken cakes 15 to 200 feet square, the largest being, of course, the thickest. When the ice could not be driven far forward it sougbt relief by lateral expansion, the cakes sliding up the bank above the water. What force these had may be realised from the fact that they totally destroyed at one blow a stone wall, the bottom of which was composed of two rows of stones, each two to eight cubic feet in bulk. They also pushed up the bank boulders and trunks of trees which had been stranded there previously. At one point the ice deposited a boulder of six cubic feet at the top of the bank. Whence this boulder came does not appear. There is no place near from which it could have come unless it was pushed up out of the river bed, which is not likely, as the river was very deep here and the lower part of the banks very steep. The most likely supposition is that it was floated down from a point a mile away, stranded near the top of the bank, and pushed up the rest of the way by cakes sliding up the bank. As the weight of it would be about 85 olbs. seven cubic yards of ice would have sufficed to float it down. It might have rolled down the bank on to the ice, having been worked out of its place by the frost. In studying the river for three winters I have had many opportunities for observing this. The crack, which is the only separation between the parent rock and a block of stone, will, if the water rises over it occasionally, be sometimes widened to a fissure nearly an inch wide, in a year, by the expansion of the water in the crack. Having once reached a width of two or three inches it will be rapidly widened by pieces of wood and roots of trees floating down at high water becoming entangled in the cracks. These act as powerful levers. If the position of the stone is favourable it will then soon slide out of place. On one of the rocks marked in the plan (Fig. I, p. 7) is a stone containing thirty cubic feet, which three years ago was only separated on two sides by cracks from the parent rock, three sides being unprotected. Now on one side is a fissure six inches wide, on another a fissure two inches wide. In this case the rapidity of the opening 
of the fissure is partly due to a tree having caught by one of its branches in it last year.

Near this boulder another one of a cubic foot was left by the ice. One hundred yards higher up the river there is a boulder weighing five tons lying half-way up the bank. It is said that this rock was originally pushed up by ice out of the river. I cannot vouch for this, but it was certainly moved a little this year, one end being turned up the bank a little farther. As it lies on other loose stones this was comparatively easy. There is also a third boulder $(c)$, which was left half-way up the bank by the ice. I think this was pushed up, as the water rose from a point lower down the bank. It contains about four cubic feet. Usually the ice goes out to sea within a few hours of its having broken up, but on this occasion it was held by the solid ice below until the water had fallen, and, therefore, some of the cakes were stranded along the bank and melted there. It is difficult to make any computation on a boulder-strewn bank as to the amount of gravel and boulders deposited by the ice, but turf can be easily distinguished. The river having sunk to its normal level in April, I went over the ground and estimated the quantity of turf and boulders lying on it in a space marked in the map (Fig. 1, p. 7). Much of the ice which stranded there had floated off without melting, and that which melted there amounted to about 7,000 square yards. Owing to the steepness of the banks in other places this strip, I,400 feet long and 40 feet wide, was the only part where much ice was left. The turf and gravel lying thereon amounted to about 808 cubic feet. Some of this turf was in strips ten or fifteen feet long and four or eight feet wide, having an average thickness of six inches. The state of the banks for the first half mile above showed that not more than one-tenth could have been derived thence, and as, above that, the banks are of rock for nearly two miles, most of this must have been floated from the meadows above. Great damage is done to these meadows every year by the ice. The ice covering a portion of this river forty miles long, or about 3,560,000 square yards in all, usually floats out to sea in the spring freshet; and also in a thaw which occurs once or twice every winter, a length of about fifteen miles, or $1,35^{\circ}, 000$ square yards more, floats out to sea. Supposing that all this ice carried the same proportion of turf and stones upon it-a fair assumption, since in the shallow, slower waters, higher up the river, it would have more opportunity of getting these than in its course between rocky banks below-it would carry out with it $55^{\circ}, 000$ cubic feet, besides the fine sand in suspension and the stones rolling along the bottom. When this figure is compared with the total area drained, it seems but a very small amount, being only ${ }_{25 \pm 6}^{2}$ of an inch in thickness for the whole 600 miles, but it must be remembered that this material is in reality drawn from an area not exceeding fifty square miles, the matter removed by the 


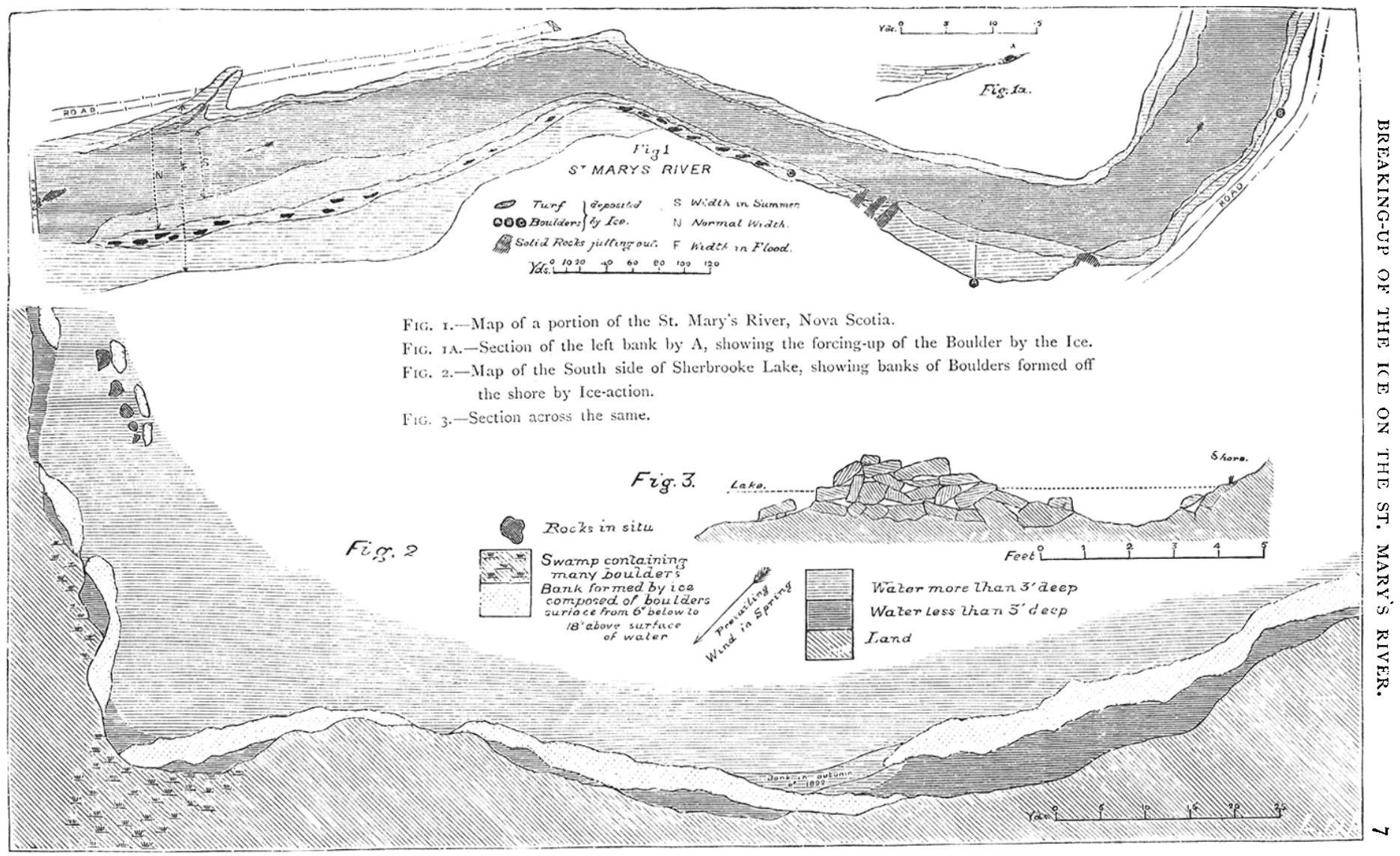


ice of the small brooks and of the main stream itself for twenty miles, being carried down the river as fine suspended sand or gravel at the hottom of the river bed.

The anchor ice, too, which may be heard grating against the solid ice sheet as it floats down, must carry away a good deal. When the river was not quite frozen over, I have seen in an opening three feet wide, where the swiftest part of the current would be, three pieces of this anchor ice, averaging nearly a cubic foot each, float down every minute. Such pieces would be able to carry earth and stones weighing more than three pounds each. And if they continue drilting in the same quantity after the river is completely frozen over, which I should judge to be the case by the sound, 4,320 such pieces would pass down this narrow strip of swift current every twenty-four hours, and these would carry nearly six tons. If, however, they were laden only in the same proportion as the ice which melted at Sherbrooke, they would carry only 38 cubic feet or about 4,000 pounds. As the river is frozen for three months, this ice could remove during this period I 80 tons, or 3,800 cubic feet. Of course there would also be large quantities of anchor ice drifting down in the slower current in the remaining width of $\mathrm{I} 80$ feet of the stream, probably twenty times as much.

The ice cakes greatly assist the water in carrying away gravel. I have seen them often, when caught in a jam, standing up on end out of the water, and being dragged in that position several yards. In this way they cut deep furrows, the material from which is at once swept away. There are now to be seen in the bed of the river some of these furrows twenty yards long and more than a foot deep. The current of this river, as it flow's at the rate of one and a-half miles, would be able to roll stones one inch in diameter (according to Geikie). The bays, in the spring, are often full of the anchor ice, previous to the breaking of the ice on the rivers. The stones in the anchor ice striate rocks on the shore. The large lakes are bordered with ridges of stones (Figs. 2 and 3 ), usually at a distance of from one to three yards from shore, which, lying in shallow water, bave been forced nearer the land by the expansion of the ice. I think these stones are deposited first in the shallows by anchor ice coming down the brooks. The drifting of the ice on the lake after it has broken also pushes the stones into ridges. The reason that they do not come nearer the shore is probably that the shallow water between them and the land, having frozen very hard, prevents it, as it does not melt till later in the season. They are not continuous, but occur chiefly in the coves at the edge of deep water.

The small brooks are greatly assisted in their work of erosion by the freezing of the ground to a considerable depth. During the winter the brooks are covered with a thick coating of ice, 


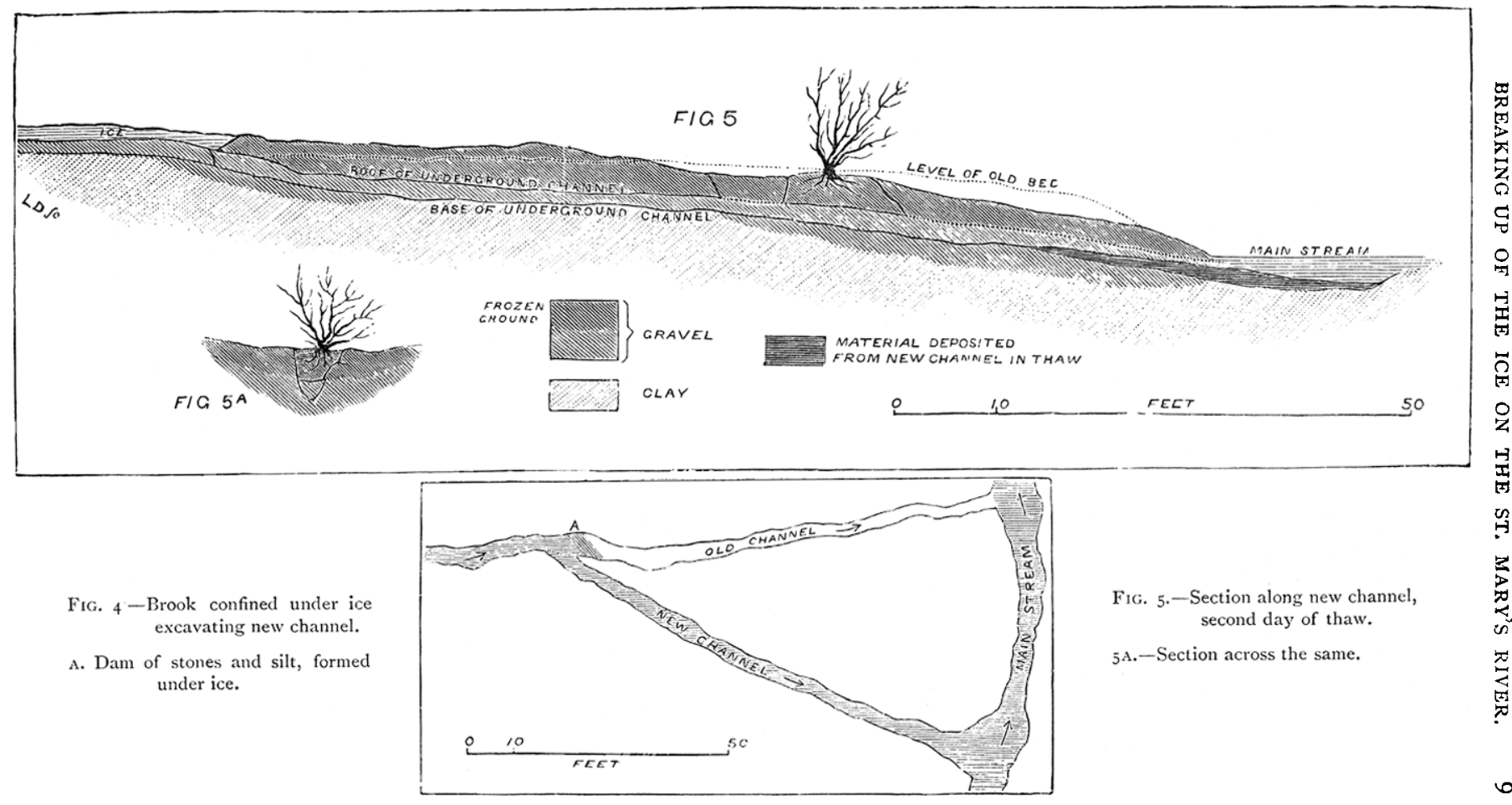


and the water, by rolling down gravel, gradually dams itself at a shallow place. Unless it can then flow over its icy covering it must find a new channel. By percolating under the frozen ground it cuts a new passage two or three feet below the surface, and when once the water flows through this in a continuous stream the pressure behind gives it considerable force, and it is enabled to rapidly enlarge the new outlet. When a thaw comes the ground above falls in and is swept away. I have seen a small brook, whose old outlet was thus damned, open a new channel by this means thirty yards long, eight feet in cross section, in four days (Figs. 4 and 5 ). The undermining had been done unnoticed, the brook appearing to have no outlet during the frost. It deposited at its mouth a delta containing about roo cubic feet, the remaining 600 cubic feet being swept down the stream into which it flowed. This same brook, on another occasion, cut a new channel twenty yards long, fifteen feet wide at the top, and three feet deep, in one winter. The material, in this case, was soft, and would not stand in steep banks. These operations are greatly assisted by the work of man in cutting away the trees, the oots of which bind the ground together. 